\title{
DEPRESSION IN PRIMARY HEALTH CARE IN CHILE: A LATENT CLASS ANALYSIS INCLUDING CLINICAL AND PSYCHOSOCIAL VARIABLES
}

Verónica Vitriol (1), Alfredo Cancino (1), Carlos Serrano ( $\left.{ }^{*} 2\right)$, Marcelo Leiva-Bianchi ( $\left.{ }^{*} 2\right)$, Soledad Ballesteros (*1) 1: Medicine School, Universidad de Talca, Chile; 2: Faculty of Psychology, Universidad de Talca, Chile; *: Psychologist

BACKGROUNDS AND AIMS: In depression, Latent Class Analysis (LCA) has mainly considered depressive symptoms. Variables such as suicide, psychiatric comorbidities and childhood trauma events, have not yet been sufficiently studied as indicators of LCA. The identification of subgroups through LCA could contribute to design differential interventions.

OBJECTIVE: To establish depressive subtypes using a LCA, including clinical and psychosocial variables in a sample of depressed patients consulting in Primary Health Care in Chile.

MATERIALS AND METHODS: 297 patients with major depression were evaluated using a clinical interview, the international mini-neuropsychiatric interview, a childhood trauma events screening, the couple violence scale and the Hamilton Depression Rating Scale. A LCA was performed.

RESULTS: A model of four latent classes were obtained according to the indicators used] AIC, BIC and Adjusted BIC. The entropy was 0.85 (table 1 )

The classes obtained were: Suicidal / recurrent; Non-suicidal / recurrent ; Suicidal / non-recurrent and Non-suicidal / non recurrent (Figure 1) (Table 2)

\begin{tabular}{|c|c|c|c|c|c|c|}
\hline $\begin{array}{c}\mathrm{N}^{\circ} \text { of } \\
\text { classes }\end{array}$ & AIC & BIC & $\begin{array}{l}\text { Adjusted } \\
\text { BIC }\end{array}$ & $\begin{array}{l}\text { LMR } \\
\text { p value }\end{array}$ & $\begin{array}{c}\text { BLRT } \\
p \text { value }\end{array}$ & $\begin{array}{c}\text { Entro- } \\
\text { py }\end{array}$ \\
\hline 3 & 3318.61 & 3436.81 & 3335.33 & .003 & $<.001$ & 0.851 \\
\hline 4 & 3308.20 & 3467.03 & 3330.66 & .019 & .020 & 0.854 \\
\hline 5 & 3309.27 & 3508.73 & 3337.48 & .412 & .428 & 0.823 \\
\hline
\end{tabular}

Figure 1: Distribution of latent classes obtained from a sample of 297 PHC depressed patients

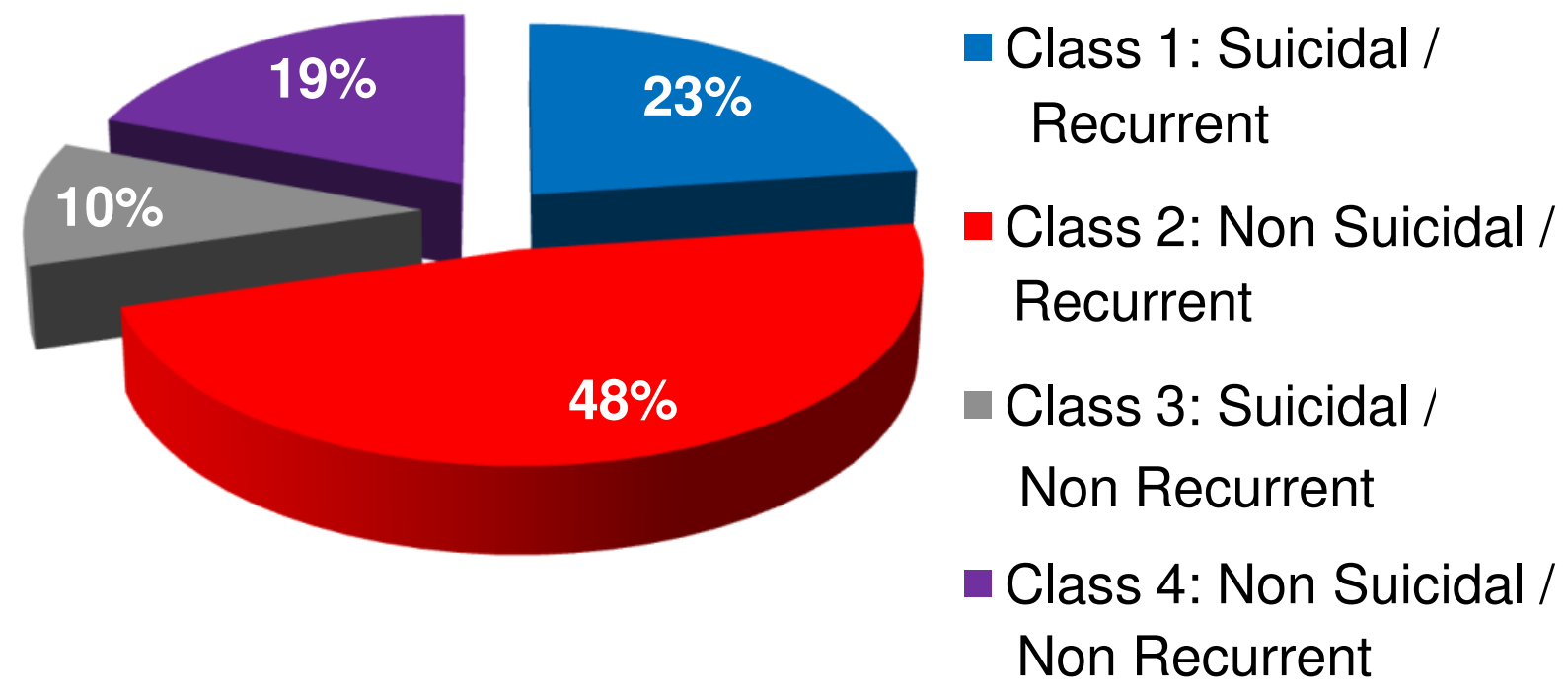

Table 2: Probabilities of a "Yes" response to each conditional item in each latent class membership in 297 Chilean PHC depressed patients.

\begin{tabular}{|c|c|c|c|c|c|c|c|c|c|}
\hline Latent class & $\begin{array}{c}\text { Suicide } \\
\text { risk }\end{array}$ & $\begin{array}{c}\text { Previous } \\
\text { suicide } \\
\text { attempt }\end{array}$ & $\begin{array}{c}\text { Previous } \\
\text { depressive } \\
\text { episode }\end{array}$ & $\begin{array}{c}\text { Treatment } \\
\text { for previous } \\
\text { depression }\end{array}$ & $\begin{array}{c}\text { Severity of } \\
\text { depressive } \\
\text { symptoms }\end{array}$ & $\begin{array}{c}\text { Child- } \\
\text { hood } \\
\text { trauma }\end{array}$ & $\begin{array}{c}\text { Intimate } \\
\text { partner } \\
\text { violence }\end{array}$ & $\begin{array}{c}\text { Psychiatric } \\
\text { comorbidity }\end{array}$ & Female sex \\
\hline $\begin{array}{c}\text { Suicidal / } \\
\text { recurrent }\end{array}$ & $\underline{1.000}$ & $\underline{0.886}$ & $\underline{0.958}$ & $\underline{0.698}$ & $\underline{0.821}$ & $\underline{0.682}$ & $\underline{0.895}$ & $\underline{1.000}$ \\
\hline $\begin{array}{c}\text { Non suicidal/ } \\
\text { recurrent }\end{array}$ & 0.333 & 0.146 & $\underline{0.977}$ & $\underline{0.602}$ & 0.634 & 0.438 & 0.716 & $\underline{1.000}$ \\
\hline $\begin{array}{c}\text { Suicidal/ } \\
\text { non recurrent }\end{array}$ & $\underline{1.000}$ & $\underline{0.417}$ & 0.000 & 0.000 & $\underline{0.823}$ & $\underline{0.657}$ & $\underline{0.870}$ & 0.642 & $\underline{0.838}$ \\
\hline $\begin{array}{c}\text { Non suicidal / } \\
\text { non recurrent }\end{array}$ & 0.091 & 0.066 & 0.000 & 0.119 & 0.516 & 0.309 & 0.533 & 0.671 \\
\hline
\end{tabular}

\section{CONCLUSIONS:}

1. This study provides additional evidence that depression could be better understood in its different subtypes, if qualitative and quantitative clinical and psychosocial indicators are included.

2. Suicidal classes were highlighted by more severe symptoms and adverse biographical backgrounds since childhood. Recurrence in the different classes were highlighted by the presence of higher comorbidity at the time of consultation.

4. The suicidal / recurrent class shows the same clinical indicators that the literature describe in patients with depression and CTEs.

5. Psychiatric comorbidity and CTEs are factors that are often not adequately diagnosed in PHC depressed patients. When these factors are present, these patients need a differentiated therapeutic approach for depression

\section{SOURCES:}

Winokur G. The concept of secondary depression and its relations to comorbidity. Psychiatr Clin North America 1990; 13(4) 567-83 Teicher M, Samson J. Childhood maltreatment and psychopathology: A case for ecophenotype variants as clinically and neurobiologically distinct subtypes. Am J Psychiatry. 2013; 170(10): 1114-33.

Nemeroff C. Paradise lost: The neurobiological and clinical consequences of child abuse and neglect. Neuron 2016; 89(5): 892-909.

Cancino, Vitriol, Ballesteros et al. Factors associated with psychiatric comorbidity in depression patients in primary health care in Chile. Depression Research and Treatment 2018; Article ID 1701978 https://doi.org/10.1155/2018/1701978 